\title{
GEM-QUALITY FRIEDELITE \\ FROM THE KALAHARI MANGANESE FIELD \\ NEAR KURUMAN, SOUTH AFRICA
}

\author{
By Herbert S. Pienaar
}

Gem-quality friedelite was discovered by chance during shaft-sinking operations in a new, deep manganese mine near Kuruman. This article reports on the general geology and mineralization of the friedelite, speculates on the age and origin of the deposit, and describes the gemological properties of this material.

The comparatively rare mineral friedelite was first reported in 1876 by Bertrand. This occurrence was in the manganese mine at Adervielle, in the Vallée du Luron of the Hautes Pyrénées, France. The mineral was named in honor of Charles Friedel, the French chemist and mineralogist.

Since then, friedelite has been recorded as occurring sporadically in other manganese silicate deposits worldwide, including the Hartig mine near Pajsberg, Sweden (Lindström, 1891); the Sjö mine near Örebro, Sweden (Ingelström, 1891); the mines near Veitsch, Austria (Hoffmann and Slavik, 1909|; the Buckwheat mine and Parker shaft, Franklin Furnace, Sussex County, New Jersey (Palache, 1910); the Taylor mine, Franklin Furnace, and the mines at Sterling Hill, Sussex County, New Jersey (Palache, 1935); the Fe-Mn deposits at Dshumart and Kamya, Central Kazahkstan, U.S.S.R. (Kuyapova, 1960); and the deposits of the Atasui region of Central Kazahkstan (Kuyapova, 1968).

It appears that only the occurrences at Franklin Furnace and Sterling Hill have produced gemquality friedelite (Sinkankas, 1959; Sinkankas, 1962; Arem, 1977; Webster, 1978). The suitability of this comparatively rare mineral for gem cutting has been mentioned by Sinkankas (1968), Vargas (1969), and Vargas (1979).

In November 1980, a little more than 100 years after its original discovery, a new occurrence of gem-quality friedelite was discovered, at the Kalahari manganese field in the Republic of South Africa. A brief description of the mineralization of this rare gem material and the circumstances that led to its discovery is presented here.

\section{MINERALIZATION}

The friedelite was found during shaft-sinking operations at the Middelplaats mine in the Kalahari manganese field, near Kuruman, northern Cape Province, Republic of South Africa (figure 1). It is associated with the lower manganese ore zone indicated in figure 2. The ore itself is a fine-grained mudstone into which the ore mineral, braunite, is incorporated in a highly disseminated state (Middelplaats Manganese Ltd., 1981).

Koekemoer, a mineral dealer, relying on information supplied by the miners who removed the friedelite from the shaft, originally placed the occurrence in the upper portion of the 25-m-thick ore zone at a depth of about $395 \mathrm{~m}$ below the surface and a distance of about $75 \mathrm{~m}$ from the main shaft (personal communication, 1981). Subsequent follow-up investigations by Zaayman, the resident mine geologist, placed the friedelite locality at the base of the lower ore body near the old ventilation shaft. Unfortunately, the precise underground position could not be determined, inasmuch as that portion of the mine, once it was worked out, had been converted into maintenance workshops and all the rock faces covered by "shotcrete," a cement aggregate applied at high pressure. Nevertheless, small fragments of friedelite were subsequently found in this vicinity (Zaayman, personal communication, 1982).

On the basis of information received from the miners, it is estimated that originally two to three tons of low-grade manganese ore were collected, from which about $100 \mathrm{~kg}$ of friedelite (then thought to be a variety of rhodochrosite) and gan-

\section{ABOUT THE AUTHOR}

Mr. Pienaar is lecturer in gemology at the De Beers Laboratory, University of Stellenbosch, Republic of South Alrica.

Acknowledgments: The author wishes to thank Crystal World Inc, Los Angeles, for specimens; the Geology Department of the Middelplaals manganese mine for supplying relevant information; and the technical staff of the Department of Geology, Stellenbosch University, for processing the manuscript.

01983 Gemological Institute of America 


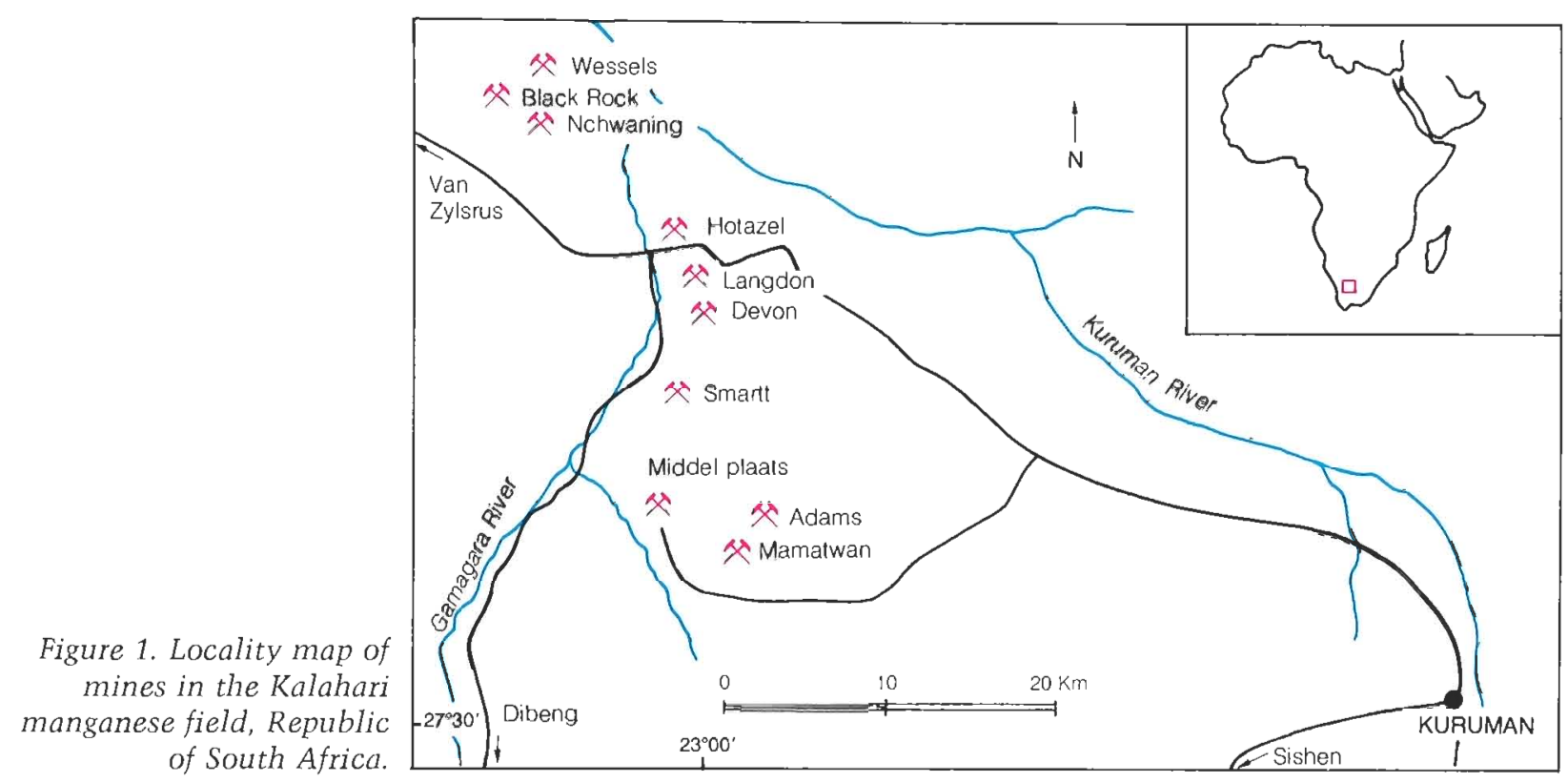

gue were later separated. According to the miners, the friedelite occurred in three discrete, near-horizontal veins within the low-grade manganiferous ironstone. As seen in large hand specimens, two of these "veins" have a thickness of about $10 \mathrm{~mm}$ and contain the pure cryptocrystalline friedelite; the third is about $35 \mathrm{~mm}$ thick and is criss-crossed by veinlets of carbonate-rich minerals, which give it a composite, matrix-like appearance.

Figure 2. Generalized section through the Middelplaats manganese mine, modified after Middelplaats Manganese Ltd. Report (1981). Vertical scale exaggerated.

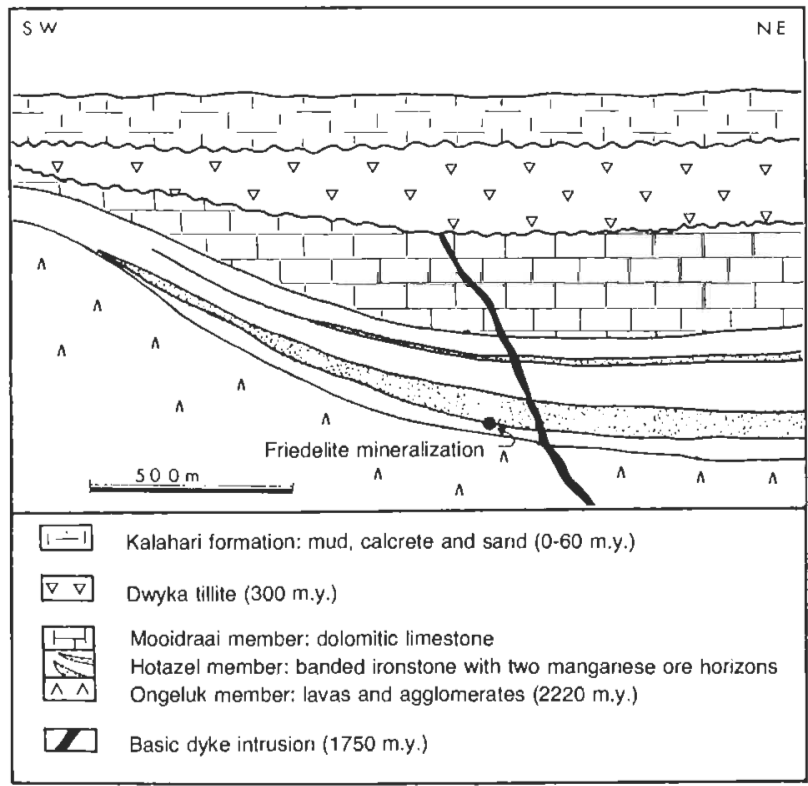

The friedelite mineralization tends to follow the general bedding of the sediments, with a slight cross-cutting relationship in places. Consequently, the origin of the friedelite occurrence is not clear. It could be metasomatic and associated with the nearby $1750-\mathrm{m}$.y.-old basic dykes, or it could be the metamorphic product of a discrete layer within the original banded ironstone formation. It is, however, definitely younger than the 2220-m.y.-old Ongeluk volcanic rocks onto which the banded ironstone formation was deposited.

\section{GENERAL GEMOLOGICAL DESCRIPTION}

Two forms of gem-quality friedelite have been found. The one is evenly colored and translucent, and has a rose red to carmine red appearance (figure 3). The other form is also predominantly rose red to carmine red, but it is streaked by pink and white veinlets of rhodochrosite and other carbonate minerals. It is referred to here as matrix friedelite (figure 4).

Ideally, the chemical composition of friedelite is $\mathrm{Mn}_{8} \mathrm{Si}_{6} \mathrm{O}_{15}(\mathrm{OH}, \mathrm{Cl})_{10}$. However, according to the accompanying electron probe analysis by $\mathrm{D}$. $\mathrm{H}$. Cornell of the Department of Geology, University of Stellenbosch, the friedelite from this occurrence has some of the manganese replaced isomorphously by iron and magnesium (table 1).

Thus far, no discrete crystals have been found in this locality. All the material examined was cryptocrystalline and optically anisotropic; it produced a typical aggregate reaction when exam- 


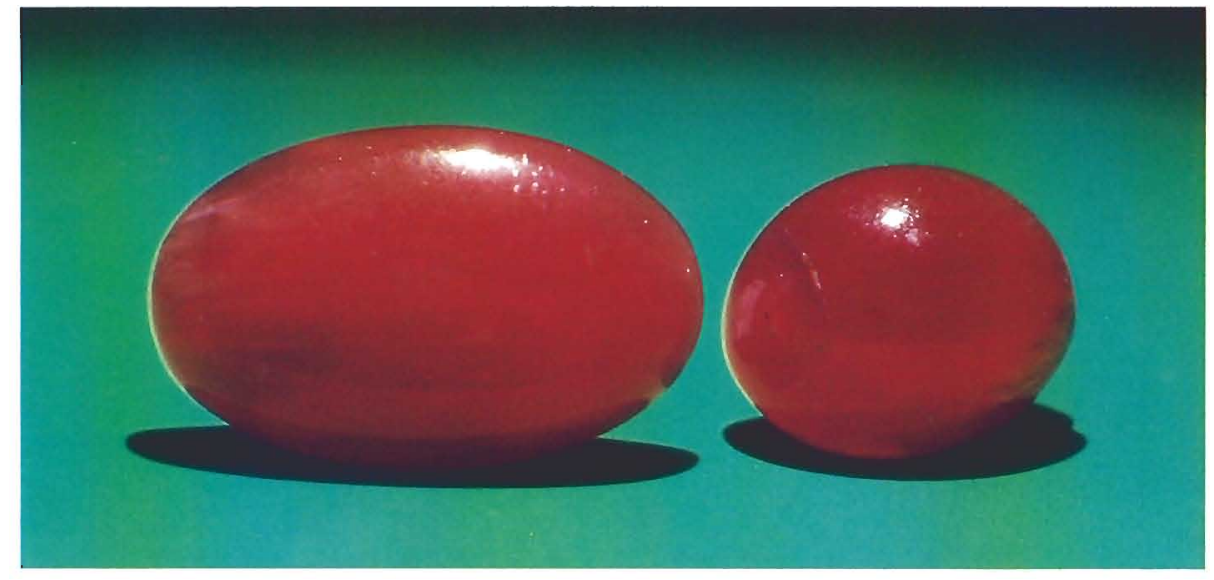

Figure 3, Cryptocrystalline friedelite cabochons, $16 \times$ $10.1 \mathrm{~mm}(5.42 \mathrm{ct})$ and 10.4 $\times 8.8 \mathrm{~mm}(3.83 \mathrm{ct})$. Photo by Tino Hammid.

ined under crossed polarizing filters. However, the X-ray diffraction powder pattern for this material agrees well with that published by Frondel and Bauer (1953) for friedelite and which they placed in the trigonal crystallographic system.

Refractive index determinations using immersion techniques gave values of $\omega=1.657$ and $\epsilon=$ 1.630. However, measurements made on a standard gemological refractometer result in a general single value of 1.64. Moreover, some gems do display "form birefringence" (Webster, 1978, p. 189) and show two distinct shadow edges, which can be separated in the usual way by a polarizing filter. The "form birefringence" values determined on 10 examples with flat facets varied from 0.005 to 0.020 , usually symmetrically placed around the mean value of 1.64 .

An examination of oriented petrographic thin sections revealed that the friedelite crystallites are spindle-shaped, with their long axes more-orless coinciding with the crystallographic c-axis. The vein-like infill is such that the spindles tend to be oriented preferentially at right angles to the plane of the bedding of the rock in which the friedelite occurs. Refractive index measurements made on polished sections oriented first parallel and then perpendicular to the plane containing the "vein" gave values of 1.64 and 1.63-1.65 respectively.

The luster on freshly broken surfaces is waxy to dull. On polished surfaces, however, it is vitreous. Polished cabochons are translucent to semitranslucent.

None of the samples of friedelite examined displayed fluorescence when exposed to long-wave ultraviolet $(365 \mathrm{~nm})$, short-wave ultraviolet (254 $\mathrm{nm})$, or X-rays.

On the hand spectroscope, the absorption spectrum shows a clear absorption band from 535 to $595 \mathrm{~nm}$, with a general absorption from 400 to $480 \mathrm{~nm}$. This absorption pattern is persistent and was observed in all specimens tested. Furthermore, as may be concluded from its absorption spectrum, friedelite has a vivid red appearance when observed through a Chelsea dichroic filter.

Other physical properties include hardness, which falls between $4 \frac{1}{2}$ and 5 on the Mohs scale; relative density for the pure material, which is $3.066 \pm 0.003$, with a slight increase up to 3.11 for matrix samples; fracture, which is even to semigranular; structure, which is massive; and toughness, which may be regarded as fair to good.

Although most of the examples of massive friedelite examined were free of any characteristic inclusions, some did show small white blebs of carbonate mineralization.

\section{DISCUSSION}

Friedelite, schallerite, and pyrosmalite form a group of minerals collectively referred to as the pyrosmalite group, with the general formula $\left.(\mathrm{Mn}, \mathrm{Fe})_{8} \mathrm{Si}_{6} \mathrm{O}_{15} \mid \mathrm{OH}, \mathrm{Cl}\right)_{10}$. Although these minerals are known to occur at times as single crystals, it is mainly the massive forms of friedelite that have been used for gem cutting.

Palache (1935) mentions a number of color varieties of friedelite occurring in the Franklin and Sterling Hill areas. These include the compact forms tinted brownish red, through the flesh-colored shades, to a "lively pink." By comparison, the friedelite from Middelplaats displays very little color variation and its reddish appearance is its main attraction. The Kazahkstan cryptocrystalline forms of friedelite described by Kuyapova in 1960 are reddish brown or a light somewhat greenish brown.

The cause of the color cannot be explained with any certainty. In broad terms, it may be as- 


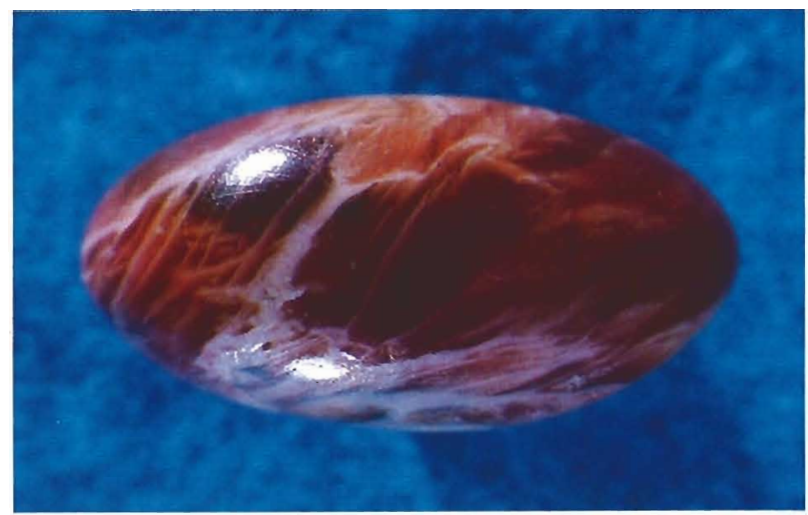

Figure 4. Matrix friedelite cabochon

$(28 \times 14 \mathrm{~mm})$.

sumed that friedelite is an idiochromatic mineral with compositional manganese as the principal colorant. Since the ferroan-friedelite described by Kuyapova (1968) is dark brown with an iron content of about $10 \%$ (reported as an oxide), and the pink friedelite described by Palache (1935) has a low iron content $( \pm 0.7 \%$ oxide $)$, the lightness or darkness of the tonal quality of the reddish color could very well be associated with the amount of iron that has isomorphously replaced the manganese. It should be pointed out, however, that the pink friedelite is also described as being a lowchlorine friedelite and its unusual pink color could also be associated with the low chlorine content $( \pm 0.25 \%)$ reported by Palache in 1935 .

The comparative rarity of friedelite is emphasized if one considers that this occurrence is the first to be reported in the Kalahari manganese field /which extends for about $500 \mathrm{~km}^{2}$; see figure 2 ), that manganese ore has been mined in a number of mines during the past 25 years, that the present discovery is limited to the originally recovered $100 \mathrm{~kg}$ of friedelite and gangue, that the geologist at Middelplaats mine had great difficulty in relocating the mineralization and could only find tiny fragments of friedelite, that the method of underground mining at depths of 250 $\mathrm{m}$ and more is highly mechanized thereby minimizing in-situ discoveries, and that the friedelite mineralization did not occur in the present ore horizons.

To date, friedelite has been encountered as a gem only rarely, while neither schallerite nor pyrosmalite has ever been recorded as such. It is quite possible that these minerals do exist as gems, but because of their similarity in appearance and durability to reddish brown varieties of bowenite serpentine, they were misidentified as
TABLE 1. Electron microprobe analysis (in wt. \%) of friedelite from the Kalahari manganese field.

\begin{tabular}{lr}
$\mathrm{SiO}_{2}$ & 35.82 \\
$\mathrm{Al}_{2} \mathrm{O}_{3}$ & 0.06 \\
$\mathrm{MgO}$ & 1.43 \\
$\mathrm{FeO}$ & 1.29 \\
$\mathrm{MnO}$ & 52.33 \\
$\mathrm{CaO}$ & - \\
$\mathrm{TiO}_{2}$ & - \\
$\mathrm{K}_{2} \mathrm{O}$ & - \\
$\mathrm{Na}_{2} \mathrm{O}$ & 0.04 \\
$\mathrm{Cl}$ & 3.59 \\
& 94.56 \\
$\mathrm{O}-\mathrm{Cl}$ & 0.81 \\
& 93.75 \\
$\mathrm{H}_{2} \mathrm{O}^{+}$ & 6.25 \\
(by difference) & \\
\hline
\end{tabular}

such. They do, however, display slightly higher values for their physical and optical properties.

\section{REFERENCES}

Arem J.E. (1977) Color Encyclopedia of Gemstones. Van Nostrand Reinhold Co., NY.

Bertrand E. (1876) Comptes Rendus de I'Academie des Sciences de France, Vol. 82, p. 1167.

Frondel C., Bauer L.H. (1953) Manganpyrosmalite and its polymorphic relation to friedelite and schallerite. American Mineralogist, Vol. 38, pp. 755-760.

Hoffmann A., Slavik F. (1909) Bulletin Acta Bohême, Vol. 14, p. 4.

Ingelström L.J. (1891) Zeitschrift für Krystallographie, Vol. 21, p. 94.

Kuyapova M.M. (1960) Friedelite from the iron-manganese deposits of Dshumart and Kamya in Central Kazahkstan. Doklady Akademii Nauk SSSR, Vol. 135, pp. 416-418.

Kuyapova M.M. (1968) Friedelite and its ferrous varieties from deposits of the Atasui region of Central Kazahkstan. Zapiski Vsesoyraznogo Mineralogicheskogo Obshchestva, Vol. 97, pp. 342-348.

Lindström G. (1891) Geologiska Föreningens i Stockholm Förhandlingar, Vol. 13, p. 81.

Middelplaats Manganese Ltd., Department of Geology (1981) A brief description of the Middelplaats manganese deposit. Unpublished report.

Palache C. (1910) Contributions to the mineralogy of Franklin Furnace, New Jersey. American Journal of Science, Vol. 29, pp. $177-187$.

Palache C. (1935) The minerals of Franklin and Sterling Hill, Sussex, New Jersey. U.S. Geological Survey Professional Paper 180, pp. 88-90.

Sinkankas J. (1959) Gemstones of North America. Van Nostrand Reinhold Co., NY.

Sinkankas J. (1962) Gem Cutting, 2nd ed. Van Nostrand Reinhold Co., NY.

Sinkankas J. (1968) Standard Catalog of Gems. Van Nostrand Reinhold Co., NY.

Vargas G., Vargas M. (1969) Faceting for Amateurs. Vargas, Thermal, CA.

Vargas G., Vargas M. (1979) Descriptions of Gem Materials. Vargas, Palm Desert, CA.

Webster R. (1978) Gems, Their Sources, Descriptions and Identification, 3rd rev. ed. Butterworth, London. 